\title{
Impact of model grid spacing on regional- and urban- scale air quality predictions of organic aerosol
}

\author{
C. A. Stroud ${ }^{1}$, P. A. Makar ${ }^{1}$, M. D. Moran ${ }^{1}$, W. Gong ${ }^{1}$, S. Gong ${ }^{1}$, J. Zhang ${ }^{1}$, K. Hayden ${ }^{1}$, C. Mihele ${ }^{1}$, J. R. Brook ${ }^{1}$, \\ J. P. D. Abbatt ${ }^{2}$, and J. G. Slowik ${ }^{2 *}$ \\ ${ }^{1}$ Air Quality Research Division, Environment Canada, Toronto, Canada \\ ${ }^{2}$ Department of Chemistry, University of Toronto, Toronto, Canada \\ *now at: Paul Scherrer Institut, Villigen, Switzerland
}

Received: 22 October 2010 - Published in Atmos. Chem. Phys. Discuss.: 13 December 2010

Revised: 10 March 2011 - Accepted: 17 March 2011 - Published: 4 April 2011

\begin{abstract}
Regional-scale chemical transport model predictions of urban organic aerosol to date tend to be biased low relative to observations, a limitation with important implications for applying such models to human exposure health studies. We used a nested version of Environment Canada's AURAMS model (42- to- 15 - to- $2.5-\mathrm{km}$ nested grid spacing) to predict organic aerosol concentrations for a temporal and spatial domain corresponding to the Border Air Quality and Meteorology Study (BAQS-Met), an air-quality field study that took place in the southern Great Lakes region in the summer of 2007. The use of three different horizontal grid spacings allowed the influence of this parameter to be examined. A domain-wide average for the $2.5-\mathrm{km}$ domain and a matching $15-\mathrm{km}$ subdomain yielded very similar organic aerosol averages ( 4.8 vs. $4.3 \mu \mathrm{g} \mathrm{m}^{-3}$, respectively). On regional scales, secondary organic aerosol dominated the organic aerosol composition and was adequately resolved by the $15-\mathrm{km}$ model simulation. However, the shape of the organic aerosol concentration histogram for the Windsor urban station improved for the $2.5-\mathrm{km}$ simulation relative to those from the 42- and 15-km simulations. The model histograms for the Bear Creek and Harrow rural stations were also improved in the high concentration "tail" region. As well the highest-resolution model results captured the midday 4 July organic-aerosol plume at Bear Creek with very good temporal correlation. These results suggest that accurate simulation of urban and large industrial plumes in the Great Lakes region requires the use of a high-resolution model in order to represent urban primary organic aerosol emissions, urban VOC emissions, and the secondary organic aerosol production rates properly. The positive feedback between the secondary organic aerosol production rate and existing organic
\end{abstract}

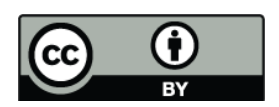

Correspondence to: C. A. Stroud (craig.stroud@ec.gc.ca) mass concentration is also represented more accurately with the highest-resolution model. Not being able to capture these finer-scale features may partly explain the consistent negative bias reported in the literature when urban-scale organic aerosol evaluations are made using coarser-scale chemical transport models.

\section{Introduction}

Atmospheric aerosols have important human health impacts and are estimated to cause more than a million premature deaths globally per year (Davidson et al., 2005). Organics comprise approximately half of atmospheric $\mathrm{PM}_{2.5}$ (particulate matter with aerodynamic diameter less than $2.5 \mu \mathrm{m}$ ) and may be a major player in the aerosol health effects. Ambient data indicate that oxygenated organic aerosol (OOA) comprises a large faction of the organic aerosol (OA) (Zhang et al., 2007). However, our understanding of the origin, transformation, and fate of OOA is poorly known. As a result, our understanding of the atmospheric OA budget is highly uncertain (Goldstein and Galbally, 2007; Hallquist et al., 2009).

Air quality (AQ) modelling systems have been developed to provide numerical forecasts of pollutant concentrations given specified emissions of the pollutants or their precursors. Modelling studies to date, however, have generally under-predicted OA concentrations, especially in urban air masses (Griffin et al., 2005; Heald et al., 2005; Chen et al., 2006; McKeen et al., 2007; Ying et al., 2007; Yu et al., 2007; Carlton et al., 2008; Murphy and Pandis, 2009; Smyth et al., 2009). There have been a number of hypotheses proposed to explain these model under-predictions, namely (1) unaccounted-for intermediate volatile organic compounds (i.e., $10^{4}<C^{*}<10^{6} \mu \mathrm{g} \mathrm{m}^{-3}$, where $C^{*}$ is the effective saturation concentration of the

Published by Copernicus Publications on behalf of the European Geosciences Union. 
IVOC) in the emissions inventories considered, (2) evaporation of semi-volatile organic compounds (SVOCs, $10^{1}<$ $C^{*}<10^{4} \mu \mathrm{g} \mathrm{m}^{-3}$ ) followed by gas-phase oxidation and condensation as secondary organic aerosol (SOA), (3) unaccounted-for biogenic VOC emissions, (4) aerosol-phase chemistry decreasing the volatility of products, (5) aqueousphase aerosol and cloud chemistry increasing the solubility of products, and (6) "older" SOA yield data collected with slower response and higher detection limit instrumentation. Recent results from the SAPRC99-PMCAM ${ }_{\mathrm{x}}$-VBS modelling system (Tsimpidi et al., 2009) address some of these processes (points 1, 2,6).

One more explanation that may affect modelled OA is model horizontal grid-cell spacing and its impact on resolving emissions of organic compounds, meteorology, and chemistry. First, it is well known that significant artificial diffusion occurs when emissions from compact sources such as point or line sources are injected into a larger model grid cell (e.g., Gillani and Pleim, 1996; Karamchandani et al., 2002). The magnitude of the artificial diffusion is directly proportional to the grid-cell size. Second, the representation of transport processes is also affected by grid spacing, since small-scale circulations may not be resolved well or at all for coarse grid spacing, a particular concern for regions of complex terrain such as the Great Lakes region of North America (e.g., Levy et al., 2010). Third, chemistry can also be affected by grid spacing, since chemical reactions in subgridscale plumes are unlikely to be accurately represented, given that chemical species within a single plume will be at least partially isolated from the ambient chemical environment of the grid cell and that two plumes of reacting species may overlap or may remain separated. This dependence has led to the development of a number of plume-in-grid approaches to represent chemistry in subgrid-scale plumes (e.g., Kumar and Russell, 1996; Karamchandani et al., 2006).

For example, Jang et al. (1995a,b) found that AQ models employing coarser grid spacing tended to underpredict ozone maxima because ozone precursors were diluted too much and to overpredict ozone minima because the representation of the NO titration process was too weak. Gillani and Pleim (1996) suggested that improved representations of urban plumes could only be achieved for horizontal grid spacing less than $20 \mathrm{~km}$. Cohan et al. (2006) suggested that to predict regional ozone patterns, the grid spacing used should be on the order of $12 \mathrm{~km}$ or less to represent ozone production and loss processes accurately. Karamchandani et al. (2002, 2006) noted that the formation of inorganic PM species such as sulphate and nitrate in a large $\mathrm{NO}_{\mathrm{x}}$ plume will be significantly slower than in the surrounding air due to oxidant limitations. Since OA has both primary and secondary sources, it is reasonable to expect that modelled OA concentrations may also display some dependence on model horizontal grid spacing.

The Border Air Quality and Meteorology Study (BAQSMet) took place in summer 2007 in the southern Great Lakes region of North America. High temporal resolution OA data were collected in southwestern Ontario at two ground sites and on board the instrumented Convair aircraft and CRUISER (Canadian Regional and Urban Investigation System for Environmental Research) mobile truck. Important local emissions of primary OA and OA precursors include mobile, area, and point sources in the Greater Detroit/Windsor urban air shed, industrial facilities along the shorelines of Lake Huron, Lake St Clair, and Lake Erie, and regional biogenic VOC sources (largely from Michigan and central and northern Ontario). The proximity of these emissions to the Great Lakes provides the opportunity for the transport and diffusion of pollutant plumes to be modified by the frequent lake- and land-breeze circulations that occur in the summer (e.g., Levy et al., 2010; Makar et al., 2010b).

The goal of this study is first to evaluate the performance of Environment Canada's A Unified Regional Air Quality Modelling System (AURAMS) for predictions of OA in urban and regionally polluted air masses during the BAQS-Met study and then to study the impact that model horizontal grid spacing has on OA concentration predictions.

\section{Method description}

\subsection{Regional air quality modelling system and configuration}

Organic aerosol mass concentrations were predicted using version 1.4.0 of AURAMS, which is an off-line regional chemical transport model (CTM) that is driven by the Canadian operational weather forecast model, GEM (Global Environmental Multiscale model) (Côté et al., 1998). Recent descriptions of AURAMS process representations can be found in the following references: chemical boundary conditions in Samaali et al. (2009) and Makar et al. (2010a); gas-phase chemistry and organic speciation in Stroud et al. (2008); biogenic SOA formation in Slowik et al. (2010); dust emissions parameterization in Park et al. (2009); vertical mixing and urban heat island effects in Makar et al. (2006); and cloud processes, aqueous-phase chemistry, and other aspects in Gong et al. (2006).

Hourly anthropogenic point, area, and mobile emissions files were prepared for the AURAMS CTM with the 2005 Canadian and 2005 US national emissions inventories and version 2.3 of the SMOKE emissions processing system (CEP, 2010). Primary organic aerosol (POA) mass emissions were determined from the bulk $\mathrm{PM}_{2.5}$ and $\mathrm{PM}_{10}$ mass emissions contained in the national inventories through the use of source-specific PM speciation profiles (e.g. mobile, non-mobile, minor point, major point). Biogenic VOC (and NO) emissions were calculated online using (1) updated BEIS v3.09 emission factors and algorithms (Schwede et al., 2005), (2) the Biogenic Emissions Landcover Database (BELD3) vegetation data set, 
and (3) GEM meteorological fields. Emissions for three VOC species were calculated: isoprene; monoterpenes; and "other VOCs". Sesquiterpene emissions are not predicted directly but are calculated as a temperature-dependent function of monoterpene emissions (Helmig et al., 2007). IVOC emissions are not accounted for in the standard national emission inventories. IVOC mass emissions were calculated by multiplying the POA mass emissions in the emission inventories by a factor of 1.5 . In the emissions processing, it is assuming that the model low volatility organic emissions (IVOCs+POA) have the same volatility distribution as in Robinson et al. (2007). The factor of 1.5 is derived from the division of the mass in Robinson et al.'s higher volatility bins $\left(C^{*}=10^{6} \mu \mathrm{g} \mathrm{m}^{-3}\right.$ bin, $C^{*}=10^{5} \mu \mathrm{g} \mathrm{m}^{-3}$ bin and half the mass in the $C^{*}=10^{4} \mu \mathrm{g} \mathrm{m}^{-3}$ bin) by the mass in Robinson et al.'s lower volatility bins (half the mass in the $C^{*}=10^{4} \mu \mathrm{g} \mathrm{m}^{-3}$ bin and all the POA mass emission in lower volatility bins.

The gas-phase chemical mechanism used in this study is an updated version of the ADOM-II mechanism that is solved with the KPP-generated third-order Rosenbrock solver (RODAS3) (Sandu and Sander, 2006). The mechanism VOC speciation was expanded to include a representation for benzene (BENZ) oxidation with the hydroxyl radical $(\mathrm{OH})$. A lumped sesquiterpene species (SESQ) was added to the ADOM-II chemical mechanism and modeled with $\beta$ caryophyllene $\mathrm{O}_{3} / \mathrm{OH} / \mathrm{NO}_{3}$ kinetics. Because detailed emissions profiles (i.e., lists of chemical species and their emission proportion by mass for individual source types) do not exist for IVOCs, several assumptions were made to handle this emissions category: (1) IVOC react with an $\mathrm{OH}$ oxidation rate coefficient of $3 \times 10^{-11} \mathrm{~cm}^{3} \mathrm{molec}^{-1} \mathrm{~s}^{-1}$ (Robinson et al., 2007); and (2) IVOC mass reacts entirely to form SOA mass (upper limit estimate). A lumped monoterpene species (PINE) was separated from the original ADOM-II long-chain alkene lumped species (ALKE) and assigned the $\mathrm{OH} / \mathrm{O}_{3} / \mathrm{NO}_{3}$ kinetics of $\alpha$-pinene.

A description of the SOA parameterization and references can be found in Slowik et al. (2010). The overall organic aerosol yield approach was applied to the following VOC precursor species: isoprene (ISOP); monoterpenes (PINE); sesquiterpenes (SESQ); benzene (BENZ); mono-substituted aromatics (TOLU); multi-substituted aromatics (AROM); long-chain anthropogenic alkenes (ALKE); and long-chain anthropogenic alkanes (ALKA). SOA yields were calculated for low- and high- $\mathrm{NO}_{\mathrm{x}}$ limits as a function of existing organic aerosol loadings (including both primary and secondary aerosol) and temperature (assumed $\Delta H_{\mathrm{vap}}=40 \mathrm{~kJ} \mathrm{~mol}^{-1}$, enthalpy of vaporization) and are based on Raoult's law equilibrium for an ideal solution composed of both POA and SOA. Updated $\alpha_{i}$ (reaction product stoichiometric coefficients) and $K_{i}$ values (gas-to-particle partitioning coefficients) are based on recent literature studies: ISOP (Kroll et al., 2006; Lane et al., 2008); PINE (Griffin et al., 1999; Zhang et al., 2006; Pathak et al., 2007); SESQ, ALKE, and
ALKA (Lane et al., 2008); BENZ and AROM (Ng et al., 2007); and TOLU (Hildebrandt et al., 2009). A linear interpolation between the low $\mathrm{NO}_{\mathrm{x}}$ and high $\mathrm{NO}_{\mathrm{x}}$ limits was performed based on the fraction of the $\mathrm{RO}_{2}$ radicals that react with $\mathrm{HO}_{\mathrm{x}}$ vs. $\mathrm{NO}_{\mathrm{x}}$ (Presto and Donahue, 2006; Henze et al., 2008).

The AURAMS CTM also incorporates the Canadian Aerosol Module (CAM), which is a size-resolved, multicomponent, sectional aerosol parameterization that accounts for nucleation, condensation, coagulation, hygroscopicity and activation, and particle deposition (Gong et al., 2003). Equilibrium inorganic gas-aerosol partitioning was solved with the vectorized HETV module (Makar et al., 2003). Dry deposition of gases is based on Weseley's resistance parameterization. In-cloud aerosol scavenging (aerosol activation to cloud droplets), below-cloud scavenging of gases and particles, evaporation, and in-cloud aqueous chemistry were solved with a cloud processes module (Gong et al., 2006). Currently, the AURAMS CTM considers 12 particlediameter size bins between 0.01 and $41 \mu \mathrm{m}$ and nine chemical components (POA, SOA, elemental carbon (EC), sulfate, nitrate, ammonium, sea-salt, crustal material, and particlebound water). An organic particle density of $1.5 \mathrm{~g} \mathrm{~cm}^{-3}$ was assumed (Murphy and Pandis, 2009) for conversion of normalized aerosol yield data (from particle volume measurements to mass). Condensation of the SOA to the particle size distribution is described by a modified Fuchs-Sutugin equation (Gong et al., 2003).

A nested grid configuration was used for the AURAMS CTM with an outer continental grid using 42-km horizontal grid spacing, an inner eastern North American grid using $15-\mathrm{km}$ horizontal grid spacing, and a fine-scale $2.5-\mathrm{km}$ grid over the BAQS-Met study region (see Fig. 2 of Makar et al., 2010b). Twenty-eight terrain-following vertical layers were used, with the lowest layer spanning $14 \mathrm{~m}$ and the model top located at $29 \mathrm{~km}$ a.g.l. AURAMS was run on the 42-km and $15-\mathrm{km}$ grids from 1 June to $15 \mathrm{July}, 2007$ and for the high resolution $2.5-\mathrm{km}$ grid for the period 1 July to 10 July 2007. Climatological chemical lateral boundary conditions (CLBC) are assumed for the 42-km continental domain. Time-dependent CLBC for the $15-\mathrm{km}$ subcontinental domain are provided by the $42-\mathrm{km}$ simulation and timedependent CLBC for the $2.5-\mathrm{km}$ southern Great Lakes domain are provided by the $15-\mathrm{km}$ simulation. The highest spatial resolution simulation needs to be numerically integrated at finer temporal resolution. The model time step was chosen proportionate to the grid size to maintain numerical stability. For this study, a 900-s time step was used for the $15-\mathrm{km}$ simulation while a 120 -s time step was used for the $2.5-\mathrm{km}$ simulation.

\subsection{Measurements}

Organic aerosol sampling by the University of Toronto (Slowik et al., 2011) during BAQS-Met took 
Table 1. Comparison of AURAMS PM 2.5 OA predictions (15-km grid spacing) with 24-h STN and IMPROVE data for 3 June-15 July 2007 (includes standard deviation of the distribution around the mean).

\begin{tabular}{|c|c|c|c|c|}
\hline Statistic & STN $15 \mathrm{~km}$ & $\mathrm{STN} 42 \mathrm{~km}$ & IMPROVE $15 \mathrm{~km}$ & IMPROVE $42 \mathrm{~km}$ \\
\hline Number of Points & 946 & 946 & 480 & 480 \\
\hline Model OA Average $\left(\mathrm{\mu g} \mathrm{m}^{-3}\right)$ & $4.8 \pm 2.7$ & $4.1 \pm 2.1$ & $3.5 \pm 2.6$ & $3.1 \pm 2.1$ \\
\hline Data OA Average $\left(\mu \mathrm{g} \mathrm{m}^{-3}\right)$ & $6.4 \pm 2.7$ & $6.4 \pm 2.7$ & $3.4 \pm 2.5$ & $3.4 \pm 2.5$ \\
\hline Best-fit Line Slope & $0.53 \pm 0.03$ & $0.40 \pm 0.02$ & $0.45 \pm 0.04$ & $0.36 \pm 0.03$ \\
\hline Best-fit Line y-intercept $\left(\mu \mathrm{g} \mathrm{m}^{-3}\right)$ & $1.4 \pm 0.2$ & $1.5 \pm 0.2$ & $2.0 \pm 0.2$ & $1.8 \pm 0.1$ \\
\hline Slope (forced y-intercept to zero) & $0.98 \pm 0.02$ & $0.602 \pm 0.009$ & $0.83 \pm 0.03$ & $0.71 \pm 0.02$ \\
\hline Mean Bias $\left(\mu \mathrm{g} \mathrm{m}^{-3}\right)$ & -1.7 & -2.4 & +0.12 & -0.34 \\
\hline $\operatorname{RMSE}\left(\mu \mathrm{g} \mathrm{m}^{-3}\right)$ & 3.2 & 3.4 & 2.7 & 2.5 \\
\hline Correlation, $R$ & 0.54 & 0.51 & 0.44 & 0.44 \\
\hline
\end{tabular}

Assumed an OA to OC ratio of 1.4 (by mass) for STN data and 1.8 (by mass) for IMPROVE data.

place at Harrow, ON from 18 June 2007 to 11 July 2007 and at Bear Creek, ON from 28 June 2007 to 10 July 2007 (see Fig. 5 for locations). Harrow is a rural site surrounded mostly by farmland that is located approximately $40 \mathrm{~km}$ southeast of the Detroit/Windsor urban area. Bear Creek is also a rural site surrounded mostly by farmland that is located approximately $60 \mathrm{~km}$ northeast of Detroit/Windsor close to the northeast shore of Lake St. Clair. The sizeresolved, non-refractory composition of submicron aerosol particles was measured with an Aerodyne time-of-flight aerosol mass spectrometer (AMS) at both sites.

Organic aerosol sampling with an AMS was also undertaken on two mobile platforms by Environment Canada: CRUISER and the instrumented Convair aircraft (Hayden et al., 2011). CRUISER was stationed for the majority of the campaign in Windsor, but did some daytime excursions eastward to intercept the Detroit/Windsor plume. The aircraft flew out of London, Ontario with some flight tracks over Lake Erie designed to capture the long-range transport of pollutants into the region and some flight tracks focusing on capturing the interaction between the Detroit/Windsor pollutant plume and the Lake St. Clair lake-breeze circulation.

In addition to direct comparisons with the continuous time-of-flight AMS measurements, simulated OA concentration was also 24-h averaged and compared to the observations from the STN (Standard Trends Network) and IMPROVE (Interagency Monitoring of Protected Visual Environments) $\mathrm{PM}_{2.5}$ speciation networks, which took 24-h samples every third day between 3 June and 15 July 2007. Samples were collected on quartz filters and analyzed for the $\mathrm{PM}_{2.5}$ OC mass concentrations. In 2007 both STN and IMPROVE used the thermo-optical reflectance (TOR) protocol to determine fine organic carbon (OC) concentrations. Factors of 1.4 and 1.8 were used to scale from OC to OA for the STN and IMPROVE networks, respectively, as suggested by Yu et al. (2004) to account for the relative age of the samples. 41 STN sites and 34 IMPROVE sites were considered over eastern North America on the 15-km grid.

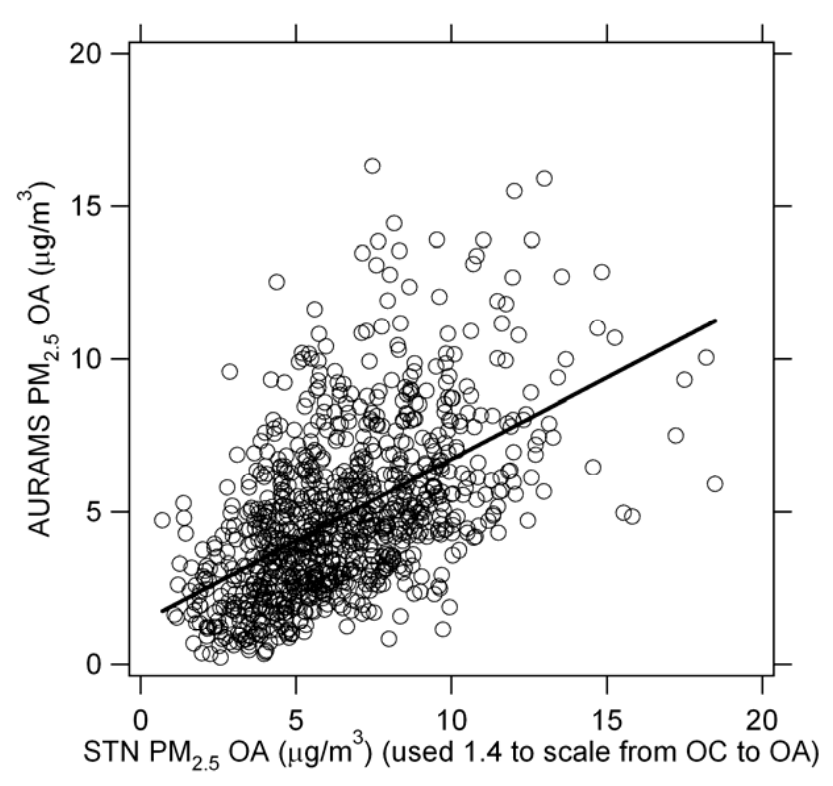

Fig. 1. Scatterplot of AURAMS predicted 24-h $\mathrm{PM}_{2.5}$ OA concentration vs. STN measured 24-h $\mathrm{PM}_{2.5}$ OA concentration for the $15-\mathrm{km}$-grid simulation for the period June 3 to 15 July 2007. The least-squares best-fit line is also plotted.

\section{Results}

\subsection{Model evaluation statistics}

Figure 1 presents a scatterplot comparing AURAMS predicted 24-h PM 2.5 OA concentration with STN measured 24$\mathrm{h} \mathrm{PM}_{2.5}$ OA concentration for the AURAMS simulation at $15-\mathrm{km}$ grid spacing. A factor of 1.4 was used to scale the measured OC to measured OA since most STN stations are sited in urban locations where fresh POA emissions are expected to dominate (Turpin and Lim, 2001). Table 1 lists the corresponding evaluation statistics for the comparison with the daily STN data. The mean \pm standard deviation 


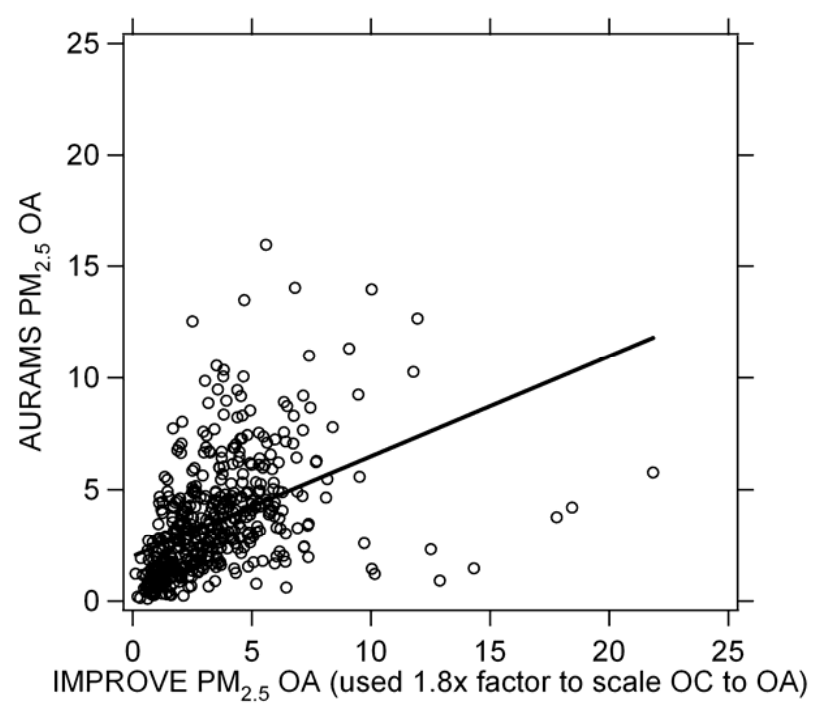

Fig. 2. Same as Fig. 1 but for the IMPROVE network.

of the STN OA measurements for all eastern sites for the BAQS-Met period was $6.4 \pm 2.7 \mu \mathrm{g} \mathrm{m}^{-3}$, which resulted in a mean model bias of $-1.7 \mu \mathrm{g} \mathrm{m}^{-3}$ and a root mean square error (RMSE) of $3.2 \mu \mathrm{g} \mathrm{m}^{-3}$ with the $15-\mathrm{km}$ grid spacing. This is a significant improvement in mean bias compared to prior order-of-magnitude OA under-predictions (e.g., McKeen et al., 2007; Smyth et al., 2009; Gong et al., 2010b), which were based on earlier OA yield data from traditional SOA precursors (Odum et al., 1996), lower monoterpene SOA yields (previously lumped monoterpenes and anthropogenic alkenes together), and no ISOP SOA, IVOC SOA or SESQ SOA production. Other recent regional AQ modelling evaluations have also observed a significant improvement in mean bias based on updated OA yield parameters and the introduction of missing SOA precursors such as evaporated SVOCs and IVOCs (Lane et al., 2008; Murphy and Pandis, 2009). The correlation coefficient, $R$, in Table 1 is 0.54 , which is comparable to correlations reported for other predicted secondary aerosol components (e.g., sulfate aerosol) over eastern North America (Gong et al., 2010a). Note that Makar et al. (2010b) showed that $\mathrm{PM}_{2.5}$ model-measurement correlation during BAQS-Met is strongly impacted by the ability of the meteorological model to simulate transport and mixing processes. For the $15-\mathrm{km}$ grid spacing, the slope and y-intercept of the best-fit line in Fig. 1 are 0.53 and $1.4 \mu \mathrm{g} \mathrm{m}^{-3}$, respectively. Table 1 also lists the model statistics for the $42-\mathrm{km}$ grid spaced simulation compared to the STN data. There is degradation in model performance in using the $42 \mathrm{~km}$ lower resolution with an increase in model bias, a decrease in correlation slope and a decrease in the regression correlation coefficient.

Figure 2 shows the corresponding comparison of AURAMS predicted 24-h $\mathrm{PM}_{2.5}$ OA concentrations with IMPROVE measurements. The IMPROVE sites are more rural in nature, which results in the sampling of more aged aerosol with higher oxygen-to-carbon composition, so a factor of 1.8 was used to scale from measured OC to measured OA (Turpin and Lim, 2001). Table 1 also lists the evaluation statistics for the comparison with the IMPROVE sites. The mean \pm standard deviation of the IMPROVE 24-h measurements for all eastern sites for the BAQS-Met period was $3.4 \pm 2.5 \mu \mathrm{g} \mathrm{m}^{-3}$. For this comparison the $15-\mathrm{km}^{2}$ resolution model marginally over-predicts, with a mean bias of $+0.12 \mu \mathrm{g} \mathrm{m}^{-3}$ and a RMSE of $2.7 \mu \mathrm{g} \mathrm{m}^{-3}$. The slope and $\mathrm{y}-$ intercept of the best-fit line in Fig. 2 are 0.45 and $2.0 \mu \mathrm{g} \mathrm{m}^{-3}$, respectively. There was only a small degradation in model performance in going to the $42-\mathrm{km}$ grid spaced simulation relative to the $15-\mathrm{km}$ grid, compared to the IMPROVE data. This likely reflects the $42-\mathrm{km}$ model grid spacing being sufficient to capture spatial and temporal variations for the IMPROVE data, which are from rural sites located in national parks. These results are consistent with another recent AURAMS evaluation study where $\mathrm{PM}_{2.5}$ was compared for the 2004 International Consortium for Atmospheric Research on Transport and Transformation (ICARTT) and 2007 BAQSMet field-study periods (Gong et al., 2010b). The summer of 2007 was considerably warmer with higher photosynthetically active radiation than 2004 , and the modeled SOA was also higher in the summer of 2007 due to increased biogenic emissions. However, the observed $\mathrm{PM}_{2.5}$ did not follow the change in temperature and radiation trend and was relatively constant between the two summers. The Gong et al. (2010b) results suggest the model had compensating errors with an over-prediction of the biogenic SOA contribution and a significant under-prediction of the anthropogenic component. A small positive bias was also reported recently for rural sites in the north-eastern US with the volatility-basis-set (VBS) parameterization in the $\mathrm{PMCAM}_{x}$ model (Lane et al., 2008).

Table 2 summarizes the comparison between AURAMS $\mathrm{PM}_{2.5}$ OA (15-km and 42-km grid spacing) with continuous AMS data from the BAQS-Met supersites at Harrow and Bear Creek. Both are rural sites but both are still in close proximity to major urban centres and major point sources). The 15-km modelled averages ( 3.8 and $4.0 \mu \mathrm{g} \mathrm{m}^{-3}$ ) for the two sites are quite similar as are the measured averages ( 6.5 and $7.1 \mu \mathrm{g} \mathrm{m}^{-3}$ ). Interestingly, the measured average at the Windsor urban site $\left(7.6 \mu \mathrm{g} \mathrm{m}^{-3}\right)$ is quite similar to those for Harrow and Bear Creek, which suggests that the Bear Creek and Harrow sites might be better classified as sub-urban rather than rural. As shown in Table 2, AURAMS underpredicts OA for all three locations. The y-intercepts for all comparisons in Table 2 are between 1.3 and $2.0 \mu \mathrm{g} \mathrm{m}^{-3}$ while the slopes are between 0.28 and 0.42. The RMSE values are also similar for all three BAQS-Met sites and the STN statistics $\left(3.2-4.8 \mu \mathrm{g} \mathrm{m}^{-3}\right)$. The correlation coefficient is similar for all three sites in Table 2. The correlation coefficients may be higher for the supersites compared to the STN and IMPROVE sites because the AMS measurements at the supersites have higher temporal resolution and can capture the 
Table 2. Comparison of AURAMS $\mathrm{PM}_{2.5}$ OA predictions (15-km and 42-km grid spacing) with 5-min average Harrow and Bear Creek AMS data and 1-min average Windsor CRUISER AMS data (includes standard deviation of the distribution around the mean).

\begin{tabular}{lrrrrrr}
\hline Statistic & $\begin{array}{r}\text { Harrow } \\
15 \mathrm{~km}\end{array}$ & $\begin{array}{r}\text { Harrow } \\
42 \mathrm{~km}\end{array}$ & $\begin{array}{r}\text { Bear Creek } \\
15 \mathrm{~km}\end{array}$ & $\begin{array}{r}\text { Bear Creek } \\
42 \mathrm{~km}\end{array}$ & $\begin{array}{r}\text { Windsor } \\
15 \mathrm{~km}\end{array}$ & $\begin{array}{r}\text { Windsor } \\
42 \mathrm{~km}\end{array}$ \\
\hline Number of Data Pairs & 4315 & 4315 & 813 & 813 & 20019 & 20019 \\
Model OA Average $\left(\mu \mathrm{g} \mathrm{m}^{-3}\right)$ & $3.8 \pm 2.1$ & $2.8 \pm 1$ & $4.0 \pm 2.5$ & $3.1 \pm 1.5$ & $5.2 \pm 2.9$ & $4.2 \pm 1.8$ \\
Data OA Average $\left(\mu \mathrm{g} \mathrm{m}^{-3}\right)$ & $6.5 \pm 4.9$ & $6.5 \pm 4.9$ & $7.1 \pm 4.9$ & $7.1 \pm 4.9$ & $7.6 \pm 4.1$ & $7.6 \pm 4.1$ \\
Slope & $0.28 \pm 0.01$ & $0.171 \pm 0.004$ & $0.38 \pm 0.01$ & $0.210 \pm 0.008$ & $0.421 \pm 0.004$ & $0.241 \pm 0.003$ \\
y-Intercept $\left(\mu \mathrm{g} \mathrm{m}^{-3}\right)$ & $1.98 \pm 0.04$ & $1.71 \pm 0.03$ & $1.3 \pm 0.1$ & $1.64 \pm 07$ & $1.97 \pm 0.03$ & $2.47 \pm 0.02$ \\
Mean Bias $\left(\mu \mathrm{g} \mathrm{m}^{-3}\right)$ & -2.7 & -3.7 & -3.1 & -4.0 & -2.4 & -3.4 \\
RMSE $\left(\mu \mathrm{g} \mathrm{m}^{-3}\right)$ & 4.8 & 5.7 & 4.7 & 5.6 & 4.1 & 4.4 \\
Correlation, $R$ & 0.65 & 0.54 & 0.72 & 0.68 & 0.60 & 0.53 \\
\hline
\end{tabular}

Table 3. Comparison of AURAMS PM 2.5 OA predictions (2.5$\mathrm{km}$ grid spacing) with aircraft 2-min average AMS data (includes standard deviation of the distribution around the mean).

\begin{tabular}{lr}
\hline Number of Data Pairs & $\begin{array}{r}\text { 371 (Flights 12-16) } \\
\text { (3 July, 7ab, 8ab)* }\end{array}$ \\
\hline Model OA Average $\left(\mu \mathrm{g} \mathrm{m}^{-3}\right)$ & $5.6 \pm 2.6$ \\
Data OA Average $\left(\mu \mathrm{g} \mathrm{m}^{-3}\right)$ & $4.2 \pm 1.5$ \\
Slope & $0.87 \pm 0.08$ \\
Intercept $\left(\mu \mathrm{g} \mathrm{m}^{-3}\right)$ & $1.9 \pm 0.3$ \\
Mean Bias $\left(\mu \mathrm{g} \mathrm{m}^{-3}\right)$ & +1.3 \\
RMSE $\left(\mu \mathrm{g} \mathrm{m}^{-3}\right)$ & 2.6 \\
Correlation, $R$ & 0.51 \\
\hline
\end{tabular}

*Total flying time was $\sim 12 \mathrm{~h}$. Most flights were during daylight hours with the exception of 7 July flight 1 (0336-0616 EST).

diurnal trend as well as synoptic fluctuations. Alternately, the lower R values for the STN and IMPROVE comparisons may indicate that the model's ability to simulate SOA varies with spatial scale, the BAQS-Met domain being a sub-portion of the model domain where the OA simulations are more accurate than the larger spatial domain. The 42-km grid spaced simulations show degradation in model performance for almost all the statistical measures at all three sites. The mean bias worsens by $\sim 1 \mu \mathrm{g} \mathrm{m}^{-3}$ in going from the $15-\mathrm{km}$ to the lower resolution $42-\mathrm{km}$ grid spacing for all three sites. The correlation coefficient, $R$, also decreases from 0.65 to 0.54 , from 0.72 to 0.68 and from 0.60 to 0.53 for Harrow, Bear Creek and Windsor, respectively.

Table 3 summarizes the high-resolution model comparison with the BAQS-Met aircraft OA concentration data. Due to the computational expense, the focus of the high-resolution model simulations was a shorter period (3-8 July 2007) during which the study area encountered higher OA concentrations. The aircraft OA measurement average was considerably lower than the surface site measurement averages. The modelled aircraft OA average was also lower than the modelled averages for the surface sites; however, the modelled concentrations were closer between the aircraft and the ground sites. In terms of evaluation statistics, the modelled results along the set of aircraft flight tracks resulted in a model positive bias of $+1.3 \mu \mathrm{g} \mathrm{m}^{-3}$ relative to the aircraft measurements. The y-intercept for the model-aircraft comparison was similar to the model y-intercepts for the surface sites. The best-fit-line slope for the model-aircraft comparison was larger than the slopes for the surface supersites and closer to the IMPROVE correlation slope, which may stem from the aircraft sampling more biogenic-influenced air masses, similar to the composition of the IMPROVE rural sites. The RMSE for the model-aircraft comparison was lower than the RMSEs for the surface supersites. Lastly, the correlation coefficient for the model-aircraft comparison was lower than for the surface sites and likely reflects a spatial correlation more than a diurnal correlation (most flights were during daytime).

\subsection{Impact of grid spacing on modelled organic aerosol time series}

Figure 3a illustrates the impact of model grid spacing for time series of observed and model-predicted OA for 3-7 June at the Bear Creek site. The simulation for $42-\mathrm{km}$ grid spacing results in a time series that is consistently lower than those for the other two higher-resolution simulations. In comparing the $15-\mathrm{km}$ and $2.5-\mathrm{km}$ simulation time series, both simulations capture temporal variations in the regional background whereas the $2.5-\mathrm{km}$ simulation better captures the higher concentration peaks.

The model concentration-frequency histogram for Bear Creek shown in Fig. 4 illustrates the improvement in the high-concentration "tail" region associated with the highestresolution simulation. The $15-\mathrm{km}$ simulation average for the 3-8 July 2007 period is $4.9 \mu \mathrm{g} \mathrm{m}^{-3}$ compared to a measured average of $7.9 \mu \mathrm{g} \mathrm{m}^{-3}$ and an average of $5.3 \mu \mathrm{g} \mathrm{m}^{-3}$ for the high-resolution $2.5-\mathrm{km}$ simulation. However, there is little change in correlation coefficient between the two 

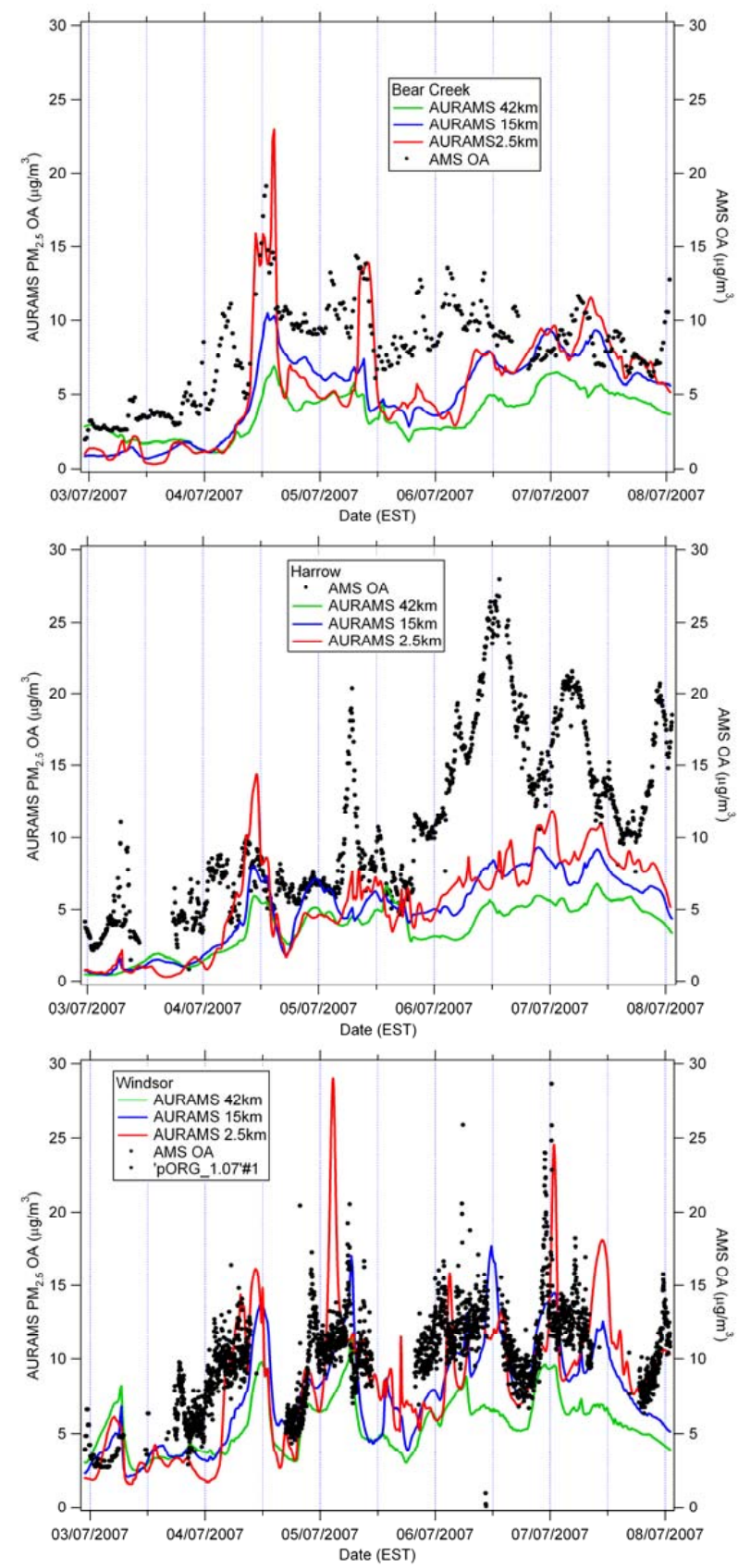

Fig. 3. OA time series comparison for the three different gridspacing AURAMS simulations $(42,15$, and $2.5 \mathrm{~km})$ at Bear Creek, Harrow, and Windsor including the AMS measurement data. . In panel $\mathrm{B}$, the AMS data is plotted on the right-hand $\mathrm{y}$-axis.

simulations: $R=0.72$ for the $15-\mathrm{km}$ simulation vs. $R=0.68$ for the $2.5-\mathrm{km}$ simulation. This result reflects the difficulty in capturing both the spatial location and temporal variation for narrow plumes, for which only small shifts in location or time can cause an anti-correlation, whereas the $15-\mathrm{km}$ grid spacing is more forgiving to near-misses.

Figure $3 \mathrm{~b}$ and $\mathrm{c}$ illustrates the impact of model grid spacing for Harrow and Windsor, respectively. In general, the same conclusions can be drawn. For Harrow, the $15-\mathrm{km}$ resolution model average for the 3-8 July 2007 period is $5.2 \mu \mathrm{g} \mathrm{m}^{-3}$ compared to a measured average of $10.8 \mu \mathrm{g} \mathrm{m}^{-3}$ and an average of $5.8 \mu \mathrm{g} \mathrm{m}^{-3}$ for the high-resolution $2.5-\mathrm{km}$ simulation. However, there is again little change in correlation coefficient in comparing the $15-\mathrm{km}$ and $2.5-\mathrm{km}$ simulations: $R=0.68$ vs. $R=0.64$. For Windsor, the $15-\mathrm{km}$ simulation average for the 3-8 July 2007 period is $7.3 \mu \mathrm{g} \mathrm{m}^{-3}$ compared to a measured average of $8.9 \mu \mathrm{g} \mathrm{m}^{-3}$ and an average of $8.2 \mu \mathrm{g} \mathrm{m}^{-3}$ for the high-resolution $2.5-\mathrm{km}$ simulation. There is a slightly larger change in correlation coefficient for Windsor between the $15-\mathrm{km}$ and $2.5-\mathrm{km}$ simulations: $R=0.68$ vs. $R=0.60$. Again this likely reflects the difficulty in capturing fine-scale features in space and time.

For all three stations the predicted time series of OA mass concentration for the 42-km simulation shown in Fig. 3 are consistently smaller than those for the two higher-resolution simulations. The $15-\mathrm{km}$ run captures the regional background adequately but the highest-resolution $2.5-\mathrm{km}$ run better captures the frequency and amplitude of OA maxima (e.g., histograms in Fig. 4). The need for high-resolution modelling for urban airsheds is illustrated in Fig. 4 by the improvement in the concentration-frequency histogram for Windsor in going from $42-\mathrm{km}$ to $15-\mathrm{km}$ to $2.5-\mathrm{km}$ grid spacing.

\subsection{Impact of grid spacing on spatial distribution of organic aerosol}

Figure 5 compares the time-averaged spatial distributions of ground-level $\mathrm{PM}_{2.5} \mathrm{OA}$ for the $15-\mathrm{km}$ and $2.5-\mathrm{km}$ simulations for the period $4 \mathrm{July}, 00 \mathrm{Z}$ to $10 \mathrm{July}, 00 \mathrm{Z}$. The average $\mathrm{PM}_{2.5}$ OA surface mass concentration over the entire 2.5$\mathrm{km}$ domain is $4.8 \pm 0.7 \mu \mathrm{g} \mathrm{m}^{-3}$ while the average $\mathrm{PM}_{2.5} \mathrm{OA}$ mass concentration for the windowed $15-\mathrm{km}$ domain corresponding to the $2.5-\mathrm{km}$ domain is $4.3 \pm 0.7 \mu \mathrm{g} \mathrm{m}^{-3}$. Both simulations result in similar OA mass concentrations for regional background grid cells (e.g., over Lake Huron). However, the higher-resolution model simulation predicts considerably higher maximum averaged grid-cell $\mathrm{PM}_{2.5}$ OA mass concentration by a factor of seven $\left(6.9 \mu \mathrm{g} \mathrm{m}^{-3}\right.$ for the $15-\mathrm{km}$ run vs. $50 \mu \mathrm{g} \mathrm{m}^{-3}$ for the $2.5-\mathrm{km}$ run).

Figures 6 and 7 compare the time-averaged spatial distributions of POA and SOA from the $15-\mathrm{km}$ and 2.5 $\mathrm{km}$ simulations for the same period. The average $\mathrm{PM}_{2.5}$ POA surface mass concentration over the $2.5-\mathrm{km}$ domain is $0.48 \pm 0.4 \mu \mathrm{g} \mathrm{m}^{-3}$ vs. $0.46 \pm 0.3 \mu \mathrm{g} \mathrm{m}^{-3}$ for the windowed $15-\mathrm{km}$ surface plot. However, the higher-resolution model run predicts a much higher maximum grid cell $\mathrm{PM}_{2.5} \mathrm{POA}$ mass concentration by a factor of $15\left(2.4 \mathrm{vs} .36 \mathrm{\mu g} \mathrm{m}^{-3}\right)$.

The time-averaged spatial distributions of $\mathrm{PM}_{2.5}$ SOA shown in Fig. 7 are more uniform spatially than the $\mathrm{PM}_{2.5}$ POA distributions since SOA formation occurs on regional 

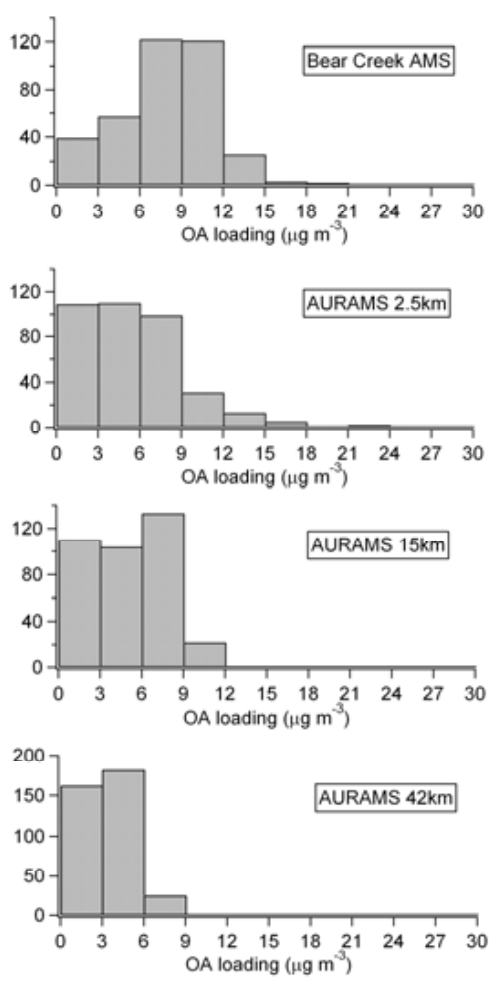
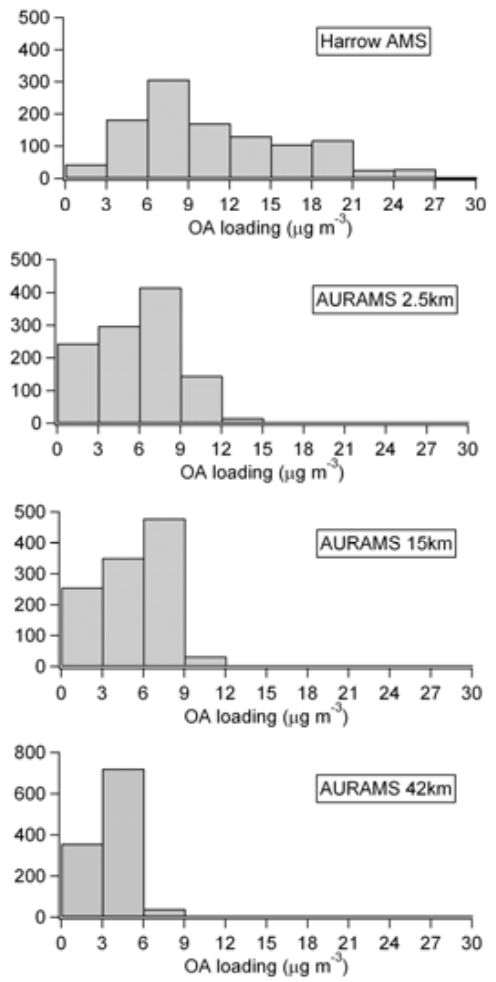
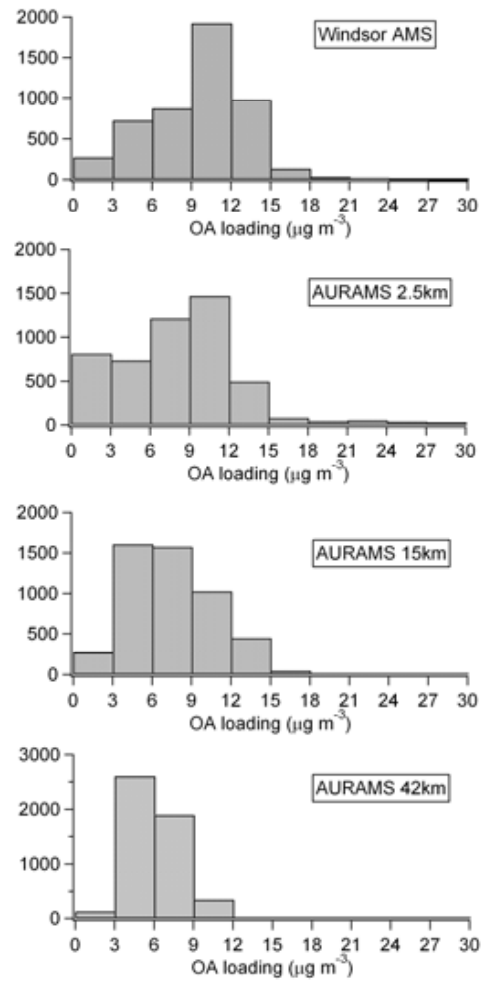

Fig. 4. Histograms (number of samples vs. concentration range) are plotted for measurement data from 3-8 July 2007. Corresponding model data are also included at 42-km, 15-km, and 2.5-km grid spacing for Bear Creek, Harrow, and Windsor.

scales. The average $\mathrm{PM}_{2.5}$ SOA surface mass concentration over the $2.5-\mathrm{km}$ domain is $4.3 \pm 0.4 \mu \mathrm{g} \mathrm{m}^{-3}$ vs. $3.9 \pm 0.4 \mu \mathrm{g} \mathrm{m}^{-3}$ for the windowed $15-\mathrm{km}$ surface plot $(9 \%$ increase), but the higher-resolution model run predicts a higher maximum grid cell $\mathrm{PM}_{2.5}$ SOA mass concentration by a factor of 3 ( $\left.5.1 \mathrm{vs} .15 \mu \mathrm{g} \mathrm{m}^{-3}\right)$.

\section{Discussion}

The increase in OA mass concentrations at higher resolutions could be due to several factors: (1) spatial variations in POA emissions are better represented for urban and industrial sources with finer-resolution grids; (2) meteorological features such as pollutant maxima along lake-breeze fronts are better resolved; (3) SOA formation chemistry depends on precursor VOC and oxidant levels, which have their own non-linear dependencies (i.e., precursor VOC levels depend on emissions their spatial resolution while oxidant levels depend on VOC levels, $\mathrm{NO}_{\mathrm{x}}$ levels, and $\mathrm{VOC} / \mathrm{NO}_{\mathrm{x}}$ ratios); and (4) the SOA partitioning process depends non-linearly on pre-existing OA mass concentrations. This last factor implies that better spatial resolution of the POA emissions may have an additional feedback on the SOA yields.
The model performance evaluation statistics in Sect. 3.3 show that the maximum grid-cell $\mathrm{PM}_{2.5}$ OA concentration change resulting from different grid spacing is greater for the POA component than the SOA component. This suggests that for grid cells with large industrial emissions (e.g., Monroe County, MI) or areas with large urban emission gradients (e.g., Toronto and Detroit plumes), the most important impact of the highest-resolution grid spacing is to better resolve the POA emissions. However, the increase in maximum SOA concentration with higher-resolution grid spacing still makes a significant contribution to the maximum gridcell $\mathrm{PM}_{2.5}$ OA concentration increase from 6.9 to $50 \mu \mathrm{g} \mathrm{m}^{-3}$. As noted above, the SOA production rates depend on precursor mixing ratios, oxidant levels, and SOA yields. Using the toluene SOA yield data for high $\mathrm{NO}_{\mathrm{x}}$ conditions $(\mathrm{Ng}$ et al., 2007) as an example, the SOA yield changes from $7 \%$ to $13 \%$ or a factor of 2 for OA concentrations changing from 6.9 to $50 \mu \mathrm{g} \mathrm{m}^{-3}$. Oxidant levels for urban air sheds are often VOC-limited or near the transition from VOC-limited to $\mathrm{NO}_{\mathrm{x}}$-limited conditions. In general, on a relative scale, $\mathrm{OH}$ and $\mathrm{O}_{3}$ concentrations change less in going from urban to sub-urban locations than do precursor VOC concentrations. Similar to the POA emissions, higher-resolution grid spacing is likely to be more important for the representation of VOC emissions and hence VOC concentrations as compared to the 

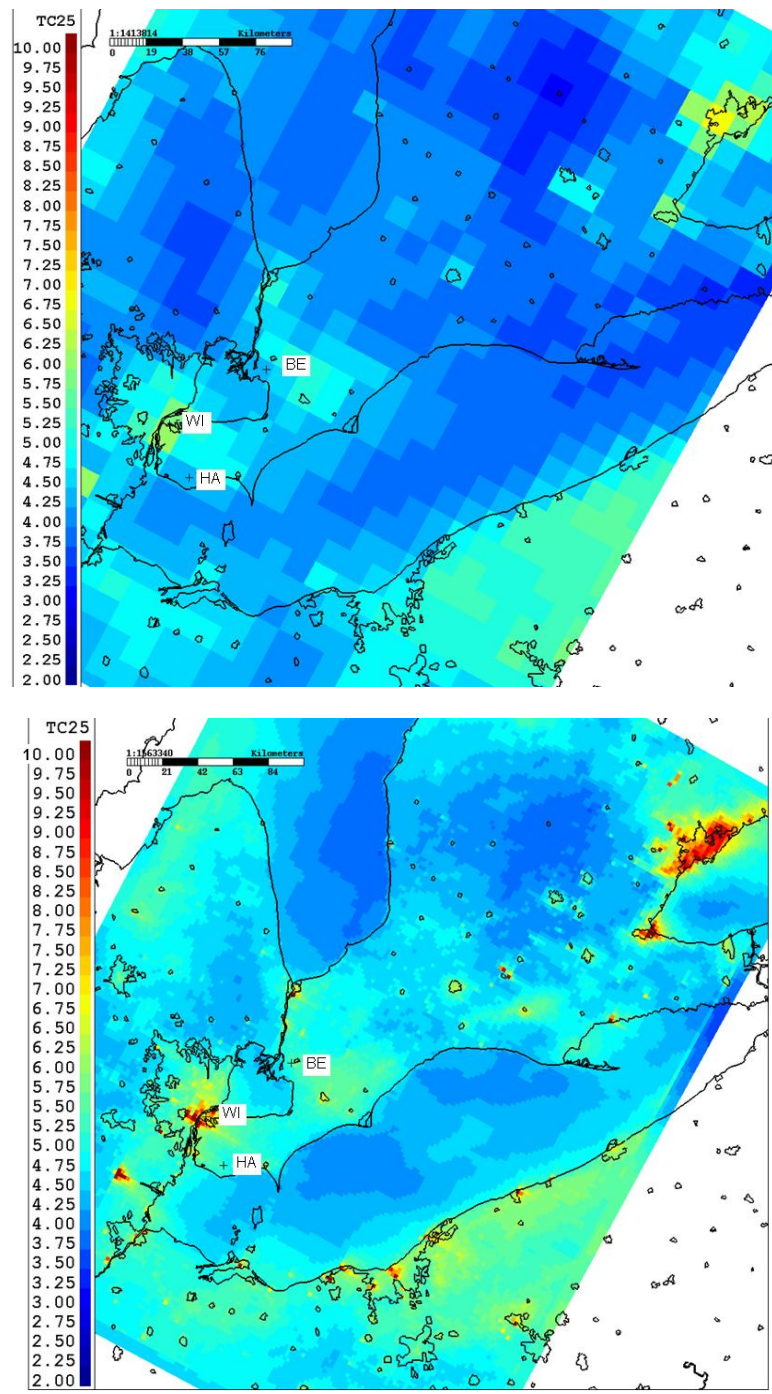

Fig. 5. Time-averaged model $\mathrm{PM}_{2.5} \mathrm{OA}$ concentration results $\left(\mu \mathrm{g} \mathrm{m}^{-3}\right)$ for (a) the windowed 15-km grid and (b) the full 2.5$\mathrm{km}$ grid (4 July, 00Z to $10 \mathrm{July}, 00 \mathrm{Z}$ ). Plus signs mark the locations of the Bear Creek ("BE"), Harrow ("HA"), and Windsor ("WI") monitoring sites.

representation of oxidant levels or SOA yields. Finer-scale meteorology likely also plays a role in better capturing finescale OA concentration features of a more episodic nature.

\section{Conclusions}

We performed predictions of $\mathrm{PM}_{2.5}$ OA with Environment Canada's AURAMS air-quality modelling system for summer 2007 for a nested grid configuration spanning continental-to-regional-to-urban scales. Modelmeasurement comparisons were made with STN and IMPROVE network data and the BAQS-Met supersite data
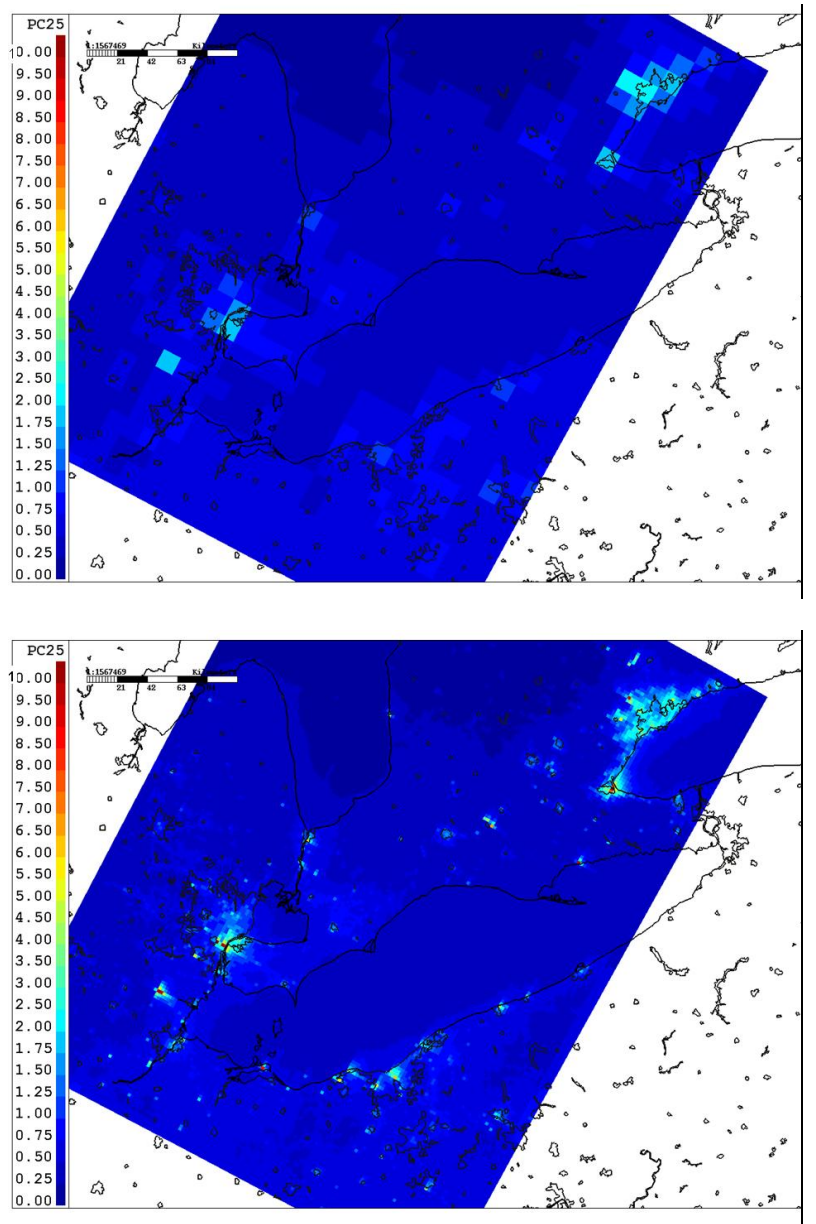

Fig. 6. Same as Fig. 5 but for $\mathrm{PM}_{2.5}$ POA results.

for the regional-scale eastern North American domain at $15-\mathrm{km}$ grid spacing. These extended time series comparisons (3 June-15 July 2007) resulted in model underpredictions of $\mathrm{PM}_{2.5} \mathrm{OA}$ vs. the STN measurements (mean bias of $-1.7 \mu \mathrm{g} \mathrm{m}^{-3}$ ) and BAQS-Met measurements (MEAN BIAS of -2.4 to $-3.1 \mu \mathrm{g} \mathrm{m}^{-3}$ ) and small overpredictions versus the IMPROVE measurements (MEAN BIAS of $\left.0.12 \mu \mathrm{g} \mathrm{m}^{-3}\right)$. These results suggest that the model is underpredicting anthropogenic SOA formation. The evaluation against one-day-in-three 24-h network OA measurements yielded correlation coefficients of 0.44 to 0.54 (largely synoptic spatial and time scales, excludes diurnal and shorter time scales) whereas evaluation with the continuous BAQSMet OA measurements yielded correlation coefficients of 0.60 to 0.72 (largely temporal, including diurnal, variations). High-resolution model-measurement comparisons with aircraft OA data $(2.5-\mathrm{km}$ grid spacing with extractions along flight tracks) yielded a MEAN BIAS of $+1.3 \mu \mathrm{g} \mathrm{m}^{-3}$ and a correlation coefficient of 0.51 . The majority of the aircraft flight time was during the day and spent characterizing aged air masses with regional-scale spatial variations. As such the 

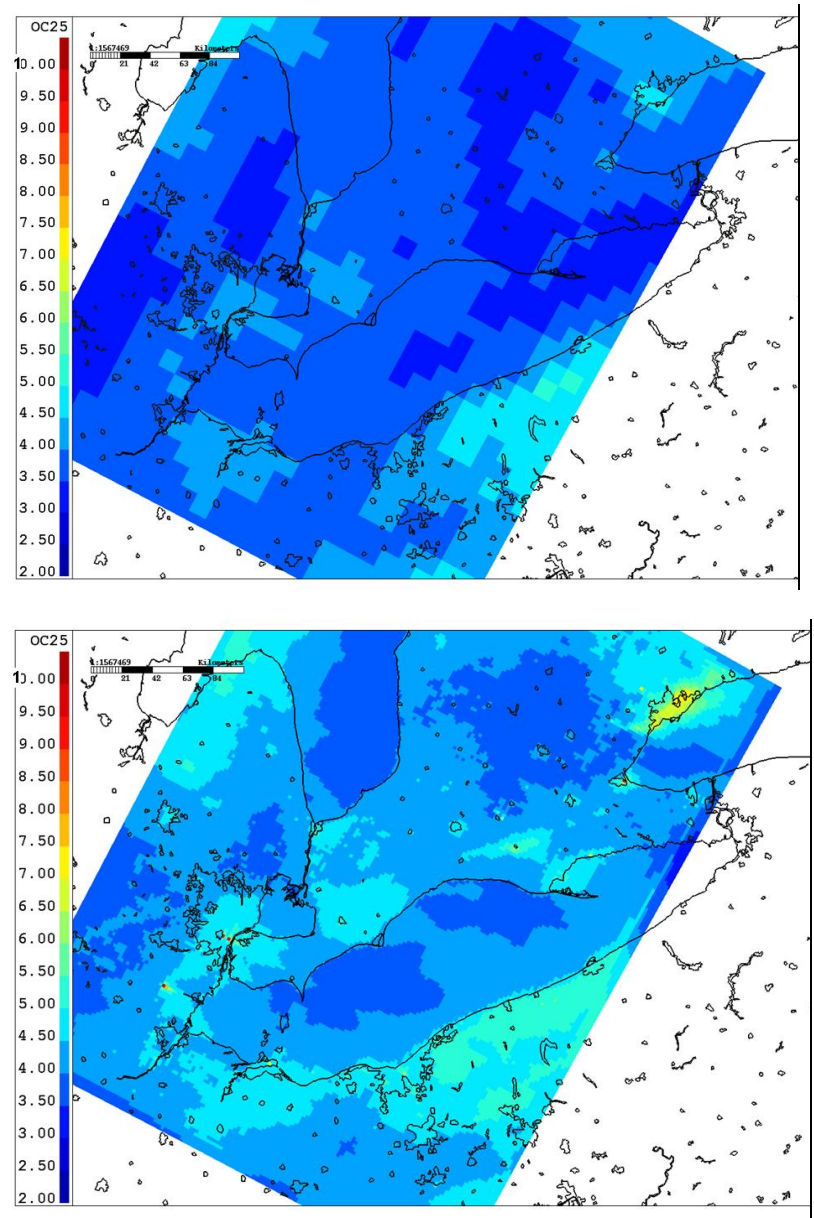

Fig. 7. Same as Fig. 5 but for $\mathrm{PM}_{2.5}$ SOA results.

model OA biases were the same sign to those calculated with data from the rural IMPROVE sites, although the positive bias is considerably higher with the aircraft data set.

In general, for the BAQS-Met supersites, the 42-km continental-scale results were consistently biased low relative to the $15-\mathrm{km}$ regional scale results. The $15-\mathrm{km}$ and 2.5-km simulations yielded similar $\mathrm{PM}_{2.5}$ OA mass concentrations for regional-scale and longer-term averages (within $9 \%$ for $15-\mathrm{km}$ windowed domain average comparison with $2.5-\mathrm{km}$ domain). However, the $2.5-\mathrm{km}$ simulation yielded a model concentration-frequency histogram for the Windsor urban site in better agreement with the measurementbased histogram compared to the $42-\mathrm{km}$ and $15-\mathrm{km}$ simulations. The model histograms for Bear Creek and Harrow were also improved in the high-concentration "tail" region, and the highest-resolution run captured the midday 4 July urban plume at Bear Creek with very good temporal correlation. Clearly, for urban and large industrial plumes, the highest spatial resolution is needed to capture spatial gradients in urban POA emissions, precursor VOC emissions, and SOA production rate. The positive feedback between SOA production rate and existing organic mass concentration is best represented with the highest spatial resolution. Overall, inadequate model grid spacing is very likely an additional factor contributing to model underprediction of urban OA measurements as reported in the literature.

Acknowledgements. The authors are grateful to the sponsors and administrators of the IMPROVE and STN networks for providing long-term aerosol composition measurements. The authors are also grateful to the Pollution Data Division of Environment Canada for emission inventory compilation and to the Canadian Meteorological Centre for development of GEM and for emissions processing support. Lastly, the authors acknowledge Environment Canada and the Ontario Ministry of the Environment for funding the BAQS-Met study.

Edited by: R. McLaren

\section{References}

Carlton, A. G., Turpin, B. J., Altieri, K. E., Seitzinger, S. P., Mathur, R., Roselle, S. J., and Weber, R. J.: CMAQ model performance enhanced when in-cloud secondary organic aerosol is included: Comparisons of organic carbon predictions with measurements, Environ. Sci. Technol., 42(23), 8798-8802, 2008.

CEP (Carolina Environmental Program): Sparse Matrix Operator Kernel Emission (SMOKE) modelling system, http:// www.smoke-model.org/index.cfm, University of North Carolina, Chapel Hill, North Carolina, 2010.

Chen, J., Mao, H., Talbot, R. W., and Griffin, R. J.: Application of the CACM and MPMPO modules using the CMAQ model for the eastern United States, J. Geophys. Res., 111, D23S25, doi:10.1029/2006JD007603, 2006.

Cohan, D. S., Hu, Y., and Russell, A. G.: Dependence of ozone sensitivity analysis on grid resolution, Atmos. Environ., 40, 126 135, 2006.

Gillani, N. V. and Pleim, J. E.: Sub-grid-scale features of anthropogenic emissions of $\mathrm{NO}_{\mathrm{x}}$ and $\mathrm{VOC}$ in the context of regional Eulerian models, Atmos. Environ., 30, 2043-2059, 1996.

Côté, J., Gravel, S., Méthot, A., Patoine, A., Roch, M., and Staniforth, A. The operational CMC-MRB global environmental multiscale (GEM) model. Part I: Design considerations and formulation, Mon. Wea. Rev., 126, 1373-1395, 1998.

Davidson, C. I., Phalen, R. F. and Solomon, P. A.: Airborne particulate matter and human health: A review, Aerosol Sci. Technol., 39, 737-749, 2005.

Goldstein, A. H. and Galbally, I. E.: Known and unexplored organic constituents in the earth's atmosphere, Environ. Sci. Technol., 41(5), 1514-1521, 2007.

Gong, S. L., Barrie, L. A., Blanchet, J.-P., von Salzen, K., Lohmann, U., Lesins, G., Spacek, L., Zhang, L.M., Girard, E., Lin, H., Leaitch, R., Leighton, H., Chylek, P. and Huang, P.: Canadian Aerosol Module: A size segregated simulation of atmospheric aerosol processes for climate and air quality models: Part 1. Module development, J. Geophys. Res., 108(D1), 4007, doi:10.1029/2001JD002002, 16 pp., 2003.

Gong, W., Dastoor, A. P., Bouchet, V. S., Gong, S., Makar, P. A., Moran, M. D., Pabla, B., Ménard, S., Crevier, L.-P., Cousineau, 
S., and Venkatesh, S.: Cloud processing of gases and aerosols in a regional air quality model (AURAMS), Atmos. Res., 82, 248$275,2006$.

Gong, W., Farrell, C., Makar, P. A., Ménard, R., Moran, M. D., Morneau, G., and Stroud, C.: Chemical Transport Models: Model Description and Evaluation, in: Environment Canada and Health Canada, Canadian Smog Science Assessment, 1, 4, Atmospheric Science and Environmental Effects, (available upon request) 2011.

Gong, W., Zhang, J., Makar, P. A., Moran, M. D., Stroud, C., Gravel, S., Gong, S. and Pabla, B.: Comparative evaluation of model simulations of regional ozone and particulate matters for two distinct summers over eastern North America, Proc. 31st NATO/SPS Intern. Tech. Mtg on Air Pollution Modelling and Its Application, $27 \mathrm{Sep}-1$ Oct, Turin, Italy, 2010b.

Griffin, R. J., Cocker III, D. R., Flagan, R. C., and Seinfeld, J. H.: Organic aerosol formation from the oxidation of biogenic hydrocarbons, J. Geophys. Res., 104, 3555-3567, 1999.

Griffin, R. J., Dabdub, D., and Seinfeld, J. H.: Development and initial evaluation of a dynamic species-resolved model for gas phase chemistry and size-resolved gas/particle partitioning associated with secondary organic aerosol formation, J. Geophys. Res, 110(5), 1-16, 2005.

Hallquist, M., Wenger, J. C., Baltensperger, U., Rudich, Y., Simpson, D., Claeys, M., Dommen, J., Donahue, N. M., George, C., Goldstein, A. H., Hamilton, J. F., Herrmann, H., Hoffmann, T., Iinuma, Y., Jang, M., Jenkin, M. E., Jimenez, J. L., Kiendler-Scharr, A., Maenhaut, W., McFiggans, G., Mentel, Th. F., Monod, A., Prévôt, A. S. H., Seinfeld, J. H., Surratt, J. D., Szmigielski, R., and Wildt, J.: The formation, properties and impact of secondary organic aerosol: current and emerging issues, Atmos. Chem. Phys., 9, 5155-5236, doi:10.5194/acp-95155-2009, 2009.

Hayden, K. L., Sills, D. M. L., Brook, J. R., Li, S.M., Makar, P., Markovic, M. Z., Liu, P., Anlauf, K. G., O’Brien, J. M., Li, Q., and McLaren, R.: Aircraft study of the impact of lake-breeze circulations on trace gases and particles during BAQS-Met 2007, Atmos. Chem. Phys. Discuss., in review, 2011.

Heald, C. L., Jacob, D. J., Park, R. J., Russell, L.M., Huebert, B.J., Seinfeld, J.H., Liao, H. and Weber, R.J. A large organic aerosol source in the free troposphere missing from current models, Geophys. Res. Let., 32 (18), L18809, 1-4, 2005.

Helmig, D., Ortega, J., Duhl, T., Tanner, D., Guenther, A., Harley, P., Wiedinmyer, C., Milford, J., and Sakulyanontvittaya, T. Sesquiterpene emissions from pine trees - identifications, emission rates and flux estimates for the contiguous United States, Environ. Sci. Technol., 41, 1545-1553, 2007.

Henze, D. K., Seinfeld, J. H., Ng, N. L., Kroll, J. H., Fu, T.-M., Jacob, D. J., and Heald, C. L.: Global modeling of secondary organic aerosol formation from aromatic hydrocarbons: High- vs. low-yield pathways, Atmos. Chem. Phys., 8, 2405-2421, 2008, http://www.atmos-chem-phys.net/8/2405/2008/.

Hildebrandt, L., Donahue, N. M., and Pandis, S. N.: High formation of secondary organic aerosol from the photooxidation of toluene, Atmos. Chem. Phys. Discuss., 9, 693-733, doi:10.5194/acpd-9-693-2009, 2009.

Jang, J.-C. C., Jeffries, H. E., Byun, D., and Pleim, J. E.: Sensitivity of ozone to model grid resolution. Part I. Application of highresolution Regional Acid Deposition Model, Atmos. Environ.,
29, 3085-3100, 1995a.

Jang, J.-C. C., Jeffries, H. E., and Tonnesen, S.: Sensitivity of ozone to model grid resolution. Part II. Detailed process analysis for ozone chemistry, Atmos. Environ., 29, 3101-3114, 1995 b.

Karamchandani, P., Seigneur, C., Vijayaraghavan, K., and Wu, S.-Y.: Development and application of a state-of-thescience plume-in-grid model, J. Geophys. Res., 107, 13 pp., doi:10.1029/2002JD002123, 2002.

Karamchandani, P., Vijayaraghavan, K., Chen, S.-Y., Seigneur, C., and Edgerton, E. S.: Plume-in-grid modeling for particulate matter, Atmos. Environ., 40, 7280-7297, 2006.

Kroll, J. H., Ng, N. L., Murphy, S. M., Flagan, R. C. and Seinfeld, J. H.: Secondary aerosol formation from isoprene photooxidaation, Environ. Sci. Technol., 40, 1869-1877, 2006.

Lane, T. E., Donahue, N. M., and Pandis, S. N.: Effect of $\mathrm{NO}_{\mathrm{x}}$ on secondary organic aerosol concentrations, Environ. Sci. Technol., 42, 6022-6027, 2008.

Levy, I., Makar, P. A., Sills, D., Zhang, J., Hayden, K. L., Mihele, C., Narayan, J., Moran, M. D., Sjostedt, S., and Brook, J. R.: Unraveling the complex local-scale flows influencing ozone patterns in the southern Great Lakes of North America, Atmos. Chem. Phys. Discuss., 10, 19763-19810, doi:10.5194/acpd-10-197632010, 2010.

Makar, P. A., Bouchet, V. S., and Nenes, A.: Inorganic chemistry calculations using HETV - a vectorized solver for the $\mathrm{SO}_{4}^{2-}-\mathrm{NO}_{3}^{-}-\mathrm{NH}_{4}^{+}$system based on the ISORROPIA algorithms, Atmos. Environ., 37, 2279-2294, 2003.

Makar, P. A., Gravel, S., Chirkov, V., Strawbridge, K. B., Froude, F., Arnold, J., and Brook, J.: Heat flux, urban properties, and regional weather, Atmos. Environ., 40, 2750-2766, 2006.

Makar, P. A., Gong, W., Mooney, C., Zhang, J., Davignon, D., Samaali, M., Moran, M. D., He, H., Tarasick, D. W., Sills, D., and Chen, J.: Dynamic Adjustment of Climatological Ozone Boundary Conditions for Air-Quality Forecasts, Atmos. Chem. Phys. Discuss., 10, 13643-13688, doi:10.5194/acpd-10-136432010, 2010.

Makar, P. A., Zhang, J., Gong, W., Stroud, C., Sills, D., Hayden, K. L., Brook, J., Levy, I., Mihele, C., Moran, M. D., Tarasick, D. W., He, H., and Plummer, D.: Mass tracking for chemical analysis: the causes of ozone formation in southern Ontario during BAQS-Met 2007, Atmos. Chem. Phys., 10, 11151-11173, doi:10.5194/acp-10-11151-2010, 2010.

McKeen, S., Chung, S. H., Wilczak, J., Grell, G., Djalalova, I., Peckham, S., Gong, W., Bouchet, V., Moffet, R., Tang, Y., Carmichael, G. R., Mathur, R. and Yu, S.: Evaluation of several real-time $\mathrm{PM}_{2.5}$ forecast models using data collected during the ICARTT/NEAQS 2004 field study, J. Geophys. Res., 112, D10S20, doi:10.1029/2006JD007608, 20 pp., 2007.

Murphy, B. N. and Pandis, S. N.: Simulating the formation of semivolatile primary and secondary organic aerosol in a regional chemical transport model, Environ. Sci. Technol., 43(13), 47224728, 2009.

Ng, N. L., Kroll, J. H., Chan, A. W. H., Chhabra, P. S., Flagan, R. C., and Seinfeld, J. H.: Secondary organic aerosol formation from m-xylene, toluene, and benzene, Atmos. Chem. Phys., 7, 3909-3922, doi:10.5194/acp-7-3909-2007, 2007

Odum, J. R., Jungkamp, T. P. W., Griffin, R. J., Flagan, R. C., and Seinfeld, J. H.: The atmospheric aerosol-forming potential of whole gasoline vapour, Science, 276(5309), 96-99, 1997. 
Pagowski, M., Grell, G. A., McKeen, S. A., Dévényi, D., Wilczak, J. M., Bouchet, V., Gong, W., McHenry, J., Peckham, S., McQueen, J., Moffet, R., and Tang, Y.: A simple method to improve ensemble-based ozone forecasts, Geophys. Res. Let., 32, L07814, 4 pp., doi:10.1029/2004GL022305, 2005.

Park, S. H., Gong, S. L., Gong, W., Makar, P. A., Moran, M. D., Stroud, C. A., and Zhang, J.: Sensitivity of surface characteristics on the simulation of wind-blown-dust source in North America, Atmos. Environ., 43(19), 3122-3129, 2009.

Pathak, R. K., Presto, A. A., Lane, T. E., Stanier, C. O., Donahue, N. M., and Pandis, S. N.: Ozonolysis of a-pinene: parameterization of secondary organic aerosol mass fraction, Atmos. Chem. Phys., 7, 3811-3821, doi:10.5194/acp-7-3811-2007, 2007.

Presto, A. A. and Donahue, N. M.: Investigation of $\alpha$ pinene + ozone secondary organic aerosol formation at low total aerosol mass, Environ. Sci. Technol., 40, 3536-3543, 2006.

Robinson, A. L., Donahue, N. M., Shrivastava, M. K., Weitkamp, E. A., Sage, A. M., Grieshop, A. P., Lane, T. E., Pierce, J. R., and Pandis, S. N.: Rethinking organic aerosols: Semivolatile emissions and photochemical aging, Science, 315(5816), 1259-1262, 2007.

Samaali, M., Moran, M. D., Bouchet, V. S., Pavlovic, R., Cousineau, S., and Sass, M.: On the influence of chemical initial and boundary conditions on annual regional air quality model simulations for North America, Atmos. Environ., 43, 48734885, 2009.

Sandu, A. and Sander, R.: Technical note: Simulating chemical systems in Fortran90 and Matlab with the Kinetic PreProcessor KPP-2.1, Atmos. Chem. Phys., 6, 187-195, doi:10.5194/acp-6187-2006, 2006.

Schwede, D., Pouliot, G., and Pierce, T.: Changes to the biogenic emissions inventory system version 3. CMAS Extended Abstract, 2005.

Slowik, J. G., Stroud, C., Bottenheim, J. W., Brickell, P. C., Chang, R. Y.-W., Liggio, J., Makar, P. A., Martin, R. V., Moran, M. D., Shantz, N. C., Sjostedt, S. J., van Donkelaar, A., Vlasenko, A., Wiebe, H. A., Xia, A. G., Zhang, J., Leaitch, W. R., and Abbatt, J. P. D.: Characterization of a large biogenic secondary organic aerosol event from eastern Canadian forests, Atmos. Chem. Phys., 10, 2825-2845, doi:10.5194/acp-10-2825-2010, 2010.

Slowik, J. G., Brook, J., Chang, R. Y.-W., Evans, G. J., Hayden, K., Jeong, C.-H., Li, S.-M., Liggio, J., Liu, P. S. K., McGuire, M., Mihele, C., Sjostedt, S., Vlasenko, A., and Abbatt, J. P. D.: Photochemical processing of organic aerosol at nearby continental sites: contrast between urban plumes and regional aerosol, Atmos. Chem. Phys. Discuss., 10, 24993-25031, doi:10.5194/acpd-10-24993-2010, 2010.
Smyth, S. C., Jiang, W., Roth, H., Moran, M. D., Makar, P. A., Yang, F., Bouchet, V. S. and Landry, H.: A comparative performance evaluation of the AURAMS and CMAQ air quality modelling systems, Atmos. Environ., 43, 1059-1070, 2009.

Stroud, C. A., Morneau, G., Makar, P. A., Moran, M. D., Gong, W., Pabla, B., Zhang, J., Bouchet, V. S., Fox, D., Venkatesh, S., Wang, D., and Dann, T.: OH-reactivity of volatile organic compounds at urban and rural sites across Canada: Evaluation of air quality model predictions using speciated VOC measurements, Atmos. Environ., 42, 7746-7756, 2008.

Tsimpidi, A. P., Karydis, V. A., Zavala, M., Lei, W., Molina, L., Ulbrich, I. M., Jimenez, J. L., and Pandis, S. N.: Evaluation of the volatility basis-set approach for the simulation of organic aerosol formation in the Mexico City metropolitan area, Atmos. Chem. Phys., 10, 525-546, doi:10.5194/acp-10-525-2010, 2010.

Turpin, B. J. and Lim, H.-J.: Species contributions to $\mathrm{PM}_{2.5}$ mass concentrations: Revisiting common assumptions for estimating organic mass, Aerosol Sci. Technol., 35(1), 602-610, 2001.

Ying, Q., Fraser, M. P., Griffin, R. J., Chen, J., and Kleeman, M. J.: Verification of a source-oriented externally mixed air quality model during a severe photochemical smog episode, Atmos. Environ., 41(7), 1521-1538, 2007.

Yu, S., Bhave, P. V., Dennis, R. L., and Mathur, R.: Seasonal and regional variations of primary and secondary organic aerosols over the continental United States: Semi-empirical estimates and model evaluation, Environ. Sci. Technol., 41(13), 4690-4697, 2007.

Yu, S., Dennis, R. L., Bhave, P. V., and Eder, B. K.: Primary and secondary organic aerosols over the United States: Estimates on the basis of observed organic carbon (OC) and elemental carbon (EC), and air quality modeled primary OC/EC ratios, Atmos.Environ., 38(31), 5257-5268, 2004.

Zhang, J., Huff Hartz, K. E., Pandis, S. N., and Donahue, N. M.: Secondary organic aerosol formation from limonene ozonolysis: Homogeneous and heterogeneous influences as a function of $\mathrm{NO}_{\mathrm{x}}$, J. Phys. Chem. A, 110, 11053-11063, 2006.

Zhang, Q., Jimenez, J. L., Canagaratna, M. R., Allan, M. R. J. D., Coe, H., Ulbrich, I., Alfarra, M. R., Takami, A., Middlebrook, A. M., Sun, Y. L., Dzepina, K., Dunlea, E., Docherty, K., DeCarlo, P. F., Salcedo, D., Onasch, T., Jayne, J. T., Miyoshi, T., Shimono, A., Hatakeyama, S., Takegawa, N., Kondo, Y., Schneider, J., Drewnick, F., Borrmann, S., Weimer, S., Demerjian, K., Williams, P., Bower, K., Bahreini, R., Cottrell, L., Griffin, R. J., Rautiainen, J., Sun, J. Y., Zhang, Y. M., and Worsnop, D. R.: Ubiquity and dominance of oxygenated species in organic aerosols in anthropogenically-influenced Northern Hemisphere midlatitudes, Geophys. Res. Lett., 34(13), L13801, doi:10.1029/2007GL029979, 2007. 